\title{
Immunological Immaturity of the Neonate, Protein Kinase C Zeta and Allergy
}

\author{
Antonio Ferrante ${ }^{1,2 *}$ and Susan L Prescott ${ }^{2,3}$ \\ ${ }^{1}$ The International Inflammation Network in-FLAME, Australia \\ ${ }^{2}$ Department of Immunology, SA pathology, Women's and Children's Hospital, Campus, North Adelaide, School of Paediatrics and Reproductive Health, Robinson Institute, \\ University of Adelaide; School of Molecular Biosciences, University of Adelaide, Australia \\ ${ }^{3}$ School of Paediatrics and Child Health, University of Western Australia, Western Australia
}

\section{Introduction}

The epidemic rise in allergic disease over the last 40 years has made prominant the urgent need to identify the developmental pathways that lead to disease. As potentially more effective interventions for allergy prevention are developed, such as primary sublingual immunotherapy, it will become crucial to accurately identify children who will develop disease. But there are currently no biological markers that have any established predictive value [1]. Cord blood IgE, the only neonatal marker to be extensively evaluated as a likely predictor, has been shown to be unreliable in this context $[1,2]$. A "family history" remains the only crude predictor of allergic disease in use [2-4].

Evidence of immunological markers of allergic propensity in the neonatal period has been presented. The development of allergic disease is frequently preceded by immunologic differences that are already evident in the neonatal period [5-10]. The most consistently observed difference has been reduced production of Interferon gamma (IFN $\gamma$ by $\mathrm{T}$ cells [5-10], suggesting that relative $\mathrm{T}$ cell immaturity may be an important contributor to disease development. Although it is not clear whether this T cell "defect" is primary or secondary to antigen presenting cell immaturity, findings support the presence of intrinsic differences in $\mathrm{T}$ cells from neonates with subsequent allergic disease. Despite the relationships between Th1 IFN $\gamma$ production and allergy risk [5-10], this has not been a reliable predictive marker because it, along with other functional measures, relies on inherently variable in vitro culturing systems with potent polyclonal stimulants that potentially distort patterns of response [1].

Early life exposures can modify $\mathrm{T}$ cell immune function. Preliminary studies also suggest that maternal environmental exposures such as infection [11], maternal diet [12,13] and smoking $[13,14]$ can modify neonatal $\mathrm{T}$ cell function, although the mechanisms are not clear. With rising disease rates, there is a continuing urgency to identify the pathways involved and to explore and monitor the effects of early interventions that could favourably influence the functional development of $\mathrm{T}$ cell responses and prevent allergic disease. Recently studies provided the first evidence that an intervention designed to reduce allergic disease had a significant effect on the protein kinase $\mathrm{C}$ (PKC) pathway [15].

\section{Immunological Immaturity of the Neonate}

Neonatal T cells are immature and lack or are poor in a number of $\mathrm{T}$ cell responses compared to cells from older babies and adults. In a study on the responses of $\mathrm{T}$ cells to the mitogen phytohaemagglutinin (PHA) in neonates versus adult blood in terms of IFN $\gamma$ production, cells from term babies produced only about $10 \%$ of the amount of IFN $\gamma$ produced by adult $\mathrm{T}$ cells. This production was compromised even more if the babies were preterm (unpublished data). This deficiency is reflected in an inability to stimulate the downstream intracellular molecules, the mitogen activated protein (MAP) kinases such as ERK and JNK [16]. In a biochemical study examining the intracellular signaling in neonatal T cells it became apparent that some of this immaturity was a result of an inadequacy in the PKC-MAP kinases signaling axis. These studies demonstrated that not only were the MAP kinase not activated after the $\mathrm{T}$ cell receptor was engaged but also when agonists acting on downstream signaling molecules/pathways of the receptor, namely PKC and calcium mobilisation stimulated by PMA and A23187 respectively [16].

However it became evident in these studies that examining the levels of the various PKC isozyme expressed by the T cells some of these isozymes were reduced in neonatal $\mathrm{T}$ cells. Cord blood $\mathrm{T}$ cells were found to be deficient in expression of PKC $\beta I, \varepsilon, \theta$, and $\zeta$ isotype [16]. Interesting as the $\mathrm{T}$ cells mature these is normalisation of these levels concomitant with an ability of $\mathrm{T}$ cells to show normal immunological responses [17].

\section{Protein Kinase $\mathrm{C}$ and Allergic Predisposition}

The 'fingerprint' pattern of neonatal T cell PKC isozyme expression significantly predicts subsequent allergic disease [15]. Moreover intervention designed to prevent allergic disease, maternal dietary supplementation with fish oil, significantly modified the expression of neonatal PKC [15]. These novel findings provide a strong basis for investigating this signaling protein further as a potential neonatal screening test for allergy prediction and potential target for disease prevention.

Evidence suggests that reduced neonatal PKC $\zeta$ expression is associated with allergy outcomes. Reduced responsiveness of neonatal $\mathrm{T}$ lymphocytes is associated with reduced expression of several PKC isozymes and reduced ability to activate MAP kinases [16]. MAP kinases differentially regulate Th1 from Th2 cytokine production [1821]. There is large individual variation in neonatal $\mathrm{T}$ cell expression in PKC isozymes, and it is therefore logical to surmise that these variations in PKC isozyme expression lead to corresponding differences in maturation characteristics, patterns of cytokine responses and disease susceptibility.

Neonatal T cell PKC isozymes are differentially expressed, with

*Corresponding author: Antonio Ferrante, Department of Immunopathology, SA Pathology, Women's and Children's Campus, University of adelaide North Adelaide, 5006, South Australia, Tel: 618881617216; E-mail: antonio.ferrante@adelaide.edu.au

Received December 15, 2013; Accepted December 15, 2013; Published December 17, 2013

Citation: Ferrante A, Prescott SL (2013) Immunological Immaturity of the Neonate Protein Kinase C Zeta and Allergy. J Neonatal Biol 3: e106. doi:10.4172/2167$0897.1000 \mathrm{e} 106$

Copyright: (c) 2013 Ferrante A, et al. This is an open-access article distributed under the terms of the Creative Commons Attribution License, which permits unrestricted use, distribution, and reproduction in any medium, provided the original author and source are credited. 
Citation: Ferrante A, Prescott SL (2013) Immunological Immaturity of the Neonate, Protein Kinase C Zeta and Allergy. J Neonatal Biol 3: e106. doi:10.4172/2167-0897.1000e106

PKC varying inversely with most other isozymes [15-17]. Examination of these PKC isozymes in relationship to allergic outcomes in a cohort of 74 "high risk" children in a previously recruited cohort, showed that increasing levels of $\mathrm{PKC \zeta}$ expression had a "protective" relationship with allergic disease and sensitisation at both 1 year and 2.5 years of age [17]. PKC $\zeta$ appeared best at predicting food allergy with significantly lower levels in neonates who developed a positive skin prick testing (SPT) to egg. Only SPT positive and not SPT negative dermatitis was associated with $\mathrm{PKC}$ expression, suggesting an association with atopy rather than dermatitis per se. Similarly, only persistent wheeze, and not early transient wheeze, was associated with PKC expression. Thus the variable inadequacy in PKC kinase signaling may play a role in the variations in neonatal $\mathrm{T}$ cell phenotype and subsequent disease risk.

\section{Neonatal T Cell PKC $\zeta$ and IFN $\gamma$ Production}

While neonatal PKC $\zeta$ was found to be significantly correlated with Th1 IFN $\gamma$ production, it was a more powerful predictor of allergic disease than the cytokine. Neonatal polyclonal IFN $\gamma$ responses were lower in children with allergic disease by 1 year [5-10,17]. Interestingly, these were significantly correlated with PKC $\zeta$ expression [17]. PKC $\zeta$ was the strongest independent predictor of allergic disease in this population. Specifically, using multivariate logistic regression with these parameters as predictor variables, only $\mathrm{PKC} \zeta$ significantly predicted allergic outcomes but not the neonatal $\mathrm{T}$ cell IFN $\gamma$ production. This effect was independent of other exposures or interventions [17].

\section{Antenatal Intervention to Modify PKC $\zeta$}

The ultimate in this new development would be to modify expression of PKC $\zeta$ in neonatal $\mathrm{T}$ cells via maternal nutrient supplementation. Maternal supplementation with $n-3$ polyunsaturated fatty acids (fish oil) in pregnancy modifies neonatal immune function. The predominant effects were seen on $\mathrm{T}$ cell responses [12,22]. It was speculated that $\mathrm{n}-3$ long chain polyunsaturated fatty acids (LCPUFA) could promote changes in developing patterns of $\mathrm{T}$ cell responses by influencing the relative pattern of PKC isozyme expression. Interestingly the suppression of neonatal $\mathrm{T}$ cell cytokine responses by fish oil [12] was associated with changes in PKC expression. Notably [17], while most isozymes were down-regulated by fish oil, $\mathrm{PKC} \zeta$ was significantly higher in the fish oil group [17]. As PKCל was shown to be an independent predictor of reduced subsequent allergic disease, this could present an important pathway through which antenatal n-3 LCPUFA could have clinical effects in reducing allergic disease [12]. It is tempting to speculate that interventions during an "early critical window" of development can alter the risk of subsequent sensitization and disease. At this stage the timing of this "critical window" is not clear, although perinatal differences in immunity of allergic individuals indicate that this is likely to be early in development $[9,23,24]$. It is therefore logical that to be most effective, preventive interventions also need to be targeted early.

\section{PKC $\zeta$ as a Screening Test}

The generated ROC (receiver operating characteristic) curves to determine optimal "cut-off" levels for predicting allergic disease demonstrated that PKC expression below $62.3 \%$ (\% of normal levels) predicted allergic disease with a sensitivity of $80 \%$ and a specificity of $63 \%$ (and accuracy of $71 \%$; the number of children correctly classified) in this "high risk" population [17]. These results were reproduced in a second cohort study in which the cumbersome western blotting analysis of $\mathrm{PKC} \zeta$ was replaced with a flow cytometry test involving intracellular staining of the protein [16]. This suggests that PKC is superior to any other biological marker assessed in this context, including cord blood IgE, which has a reported sensitivity of only $26-47 \%$ [2-4,25]. Although other parameters have been examined previously, including eosinophil levels, histamine reactions and leukocyte phosphodiesterase levels, none had an accuracy of more than 58\% [26].

\section{Concluding Remarks}

The finding that neonatal $\mathrm{T}$ cell $\mathrm{PKC} \zeta$ expression is lower in allergic children, and that this isozyme is also significantly enhanced by increased membrane n-3 LCPUFA content, opens new horizons in developmental immunology in which levels of intracellular signaling molecules may be amenable as markers of $\mathrm{T}$ cell development. Variations in these may be relevant to functional immune phenotype and disease development. This not only provides further evidence that environmental interventions can significantly modify neonatal $\mathrm{T}$ cell function, but also suggests that PKC $\zeta$ should be explored further as a marker of disease risk. As disease prevention strategies become more refined "risk markers" will be of increasing importance to target interventions and to assess their effects.

Reduced neonatal PKC $\zeta$ expression in subsequently allergic children was detected in resting cells without the need for stimulation or culture. Accordingly, the "predictive" effect of PKC $\zeta$ is far greater than IFN $\gamma$ Th1 responses, which depend in inherently variable functional in vitro culturing systems. As there are no reliable early markers to predict allergic disease, the PKCל marker should be explored further in this context, particularly as this approach avoids in vitro manipulations and could be more readily standardised. In addition through a better understanding of these pathways we may improve avenues for more targeted treatment and prevention of allergic diseases.

\section{Acknowledgement}

The authors' work is supported by funds from the NHMRC of Australia.

\section{References}

1. Allam JP, Zivanovic O, Berg C, Gembruch U, Bieber T, et al. (2005) In search for predictive factors for atopy in human cord blood. Allergy 60: 743-750.

2. Hide DW, Arshad SH, Twiselton R, Stevens M (1991) Cord serum IgE: an insensitive method for prediction of atopy. Clin Exp Allergy 21: 739-743.

3. Bergmann RL, Edenharter G, Bergmann KE, Guggenmoos-Holzmann I, Forster J, et al. (1997) Predictability of early atopy by cord blood-lgE and parental history. Clin Exp Allergy 27: 752-760.

4. Hansen LG, Halken S, Høst A, Møller K, Osterballe O (1993) Prediction of allergy from family history and cord blood IgE levels. A follow-up at the age of 5 years. Cord blood IgE. IV. Pediatr Allergy Immunol 4: 34-40.

5. Tang ML, Kemp AS, Thorburn J, Hill DJ (1994) Reduced interferon-gamma secretion in neonates and subsequent atopy. Lancet 344: 983-985.

6. Warner JA, Miles EA, Jones AC, Quint DJ, Colwell BM, et al. (1994) Is deficiency of interferon gamma production by allergen triggered cord blood cells a predictor of atopic eczema? Clin Exp Allergy 24: 423-430.

7. Martinez FD, Stern DA, Wright AL, Holberg CJ, Taussig LM, et al. (1995) Association of interleukin-2 and interferon-gamma production by blood mononuclear cells in infancy with parental allergy skin tests and with subsequent development of atopy. J Allergy Clin Immunol 96: 652-660.

8. Kondo N, Kobayashi Y, Shinoda S, Takenaka R, Teramoto T, et al. (1998) Reduced interferon gamma production by antigen-stimulated cord blood mononuclear cells is a risk factor of allergic disorders--6-year follow-up study. Clin Exp Allergy 28: 1340-1344

9. Prescott SL, Macaubas C, Smallacombe T, Holt BJ, Sly PD, et al. (1999) Development of allergen-specific T-cell memory in atopic and normal children. Lancet 353: 196-200.

10. Prescott SL, Macaubas C, Smallacombe T, Holt BJ, Sly PD, et al. (1998) Reciprocal age-related patterns of allergen-specific T-cell immunity in norma vs. atopic infants. Clin Exp Allergy 28 Suppl 5: 39-44. 
Citation: Ferrante A, Prescott SL (2013) Immunological Immaturity of the Neonate, Protein Kinase C Zeta and Allergy. J Neonatal Biol 3: e106. doi:10.4172/2167-0897.1000e106

Pge 3 of 3

11. Matsuoka T, Matsubara T, Katayama K, Takeda K, Koga M, et al. (2001) Increase of cord blood cytokine-producing $T$ cells in intrauterine infection. Pediatr Int 43: 453-457.

12. Dunstan JA, Mori TA, Barden A, Beilin LJ, Taylor AL, et al. (2003) Fish oil supplementation in pregnancy modifies neonatal allergen-specific immune responses and clinical outcomes in infants at high risk of atopy: a randomized, controlled trial. J Allergy Clin Immunol 112: 1178-1184.

13. Devereux G, Barker RN, Seaton A (2002) Antenatal determinants of neonatal immune responses to allergens. Clin Exp Allergy 32: 43-50.

14. Noakes PS, Holt PG, Prescott SL (2003) Maternal smoking in pregnancy alters neonatal cytokine responses. Allergy 58: 1053-1058.

15. Prescott SL, Irvine J, Dunstan JA, Hii C, Ferrante A (2007) Protein kinase Czeta: a novel protective neonatal T-cell marker that can be upregulated by allergy prevention strategies. J Allergy Clin Immunol 120: 200-206.

16. Hii CS, Costabile M, Mayne GC, Der CJ, Murray AW, et al. (2003) Selective deficiency in protein kinase $C$ isoenzyme expression and inadequacy in mitogen-activated protein kinase activation in cord blood $\mathrm{T}$ cells. Biochem $\mathrm{J}$ 370: 497-503.

17. D'Vaz N, Ma Y, Dunstan JA, Lee-Pullen TF, Hii C, et al. (2012) Neonatal protein kinase $C$ zeta expression determines the neonatal T-Cell cytokine phenotype and predicts the development and severity of infant allergic disease. Allergy 67: 1511-1518.

18. Egerton M, Fitzpatrick DR, Kelso A (1998) Activation of the extracellular signal-regulated kinase pathway is differentially required for TCR-stimulated production of six cytokines in primary T lymphocytes. Int Immunol 10: 223-229.
19. Rincón M, Flavell RA, Davis RA (2000) The JNK and P38 MAP kinase signaling pathways in T cell-mediated immune responses. Free Radic Biol Med 28: 13281337.

20. Li YQ, Hii CS, Der CJ, Ferrante A (1999) Direct evidence that ERK regulates the production/secretion of interleukin-2 in PHA/PMA-stimulated T lymphocytes. Immunology 96: 524-528.

21. Melino M, Hii CS, McColl SR, Ferrante A (2008) The effect of the JNK inhibitor JIP peptide, on human $\mathrm{T}$ lymphocyte proliferation and cytokine production. $J$ Immunol 181: 7300-7306.

22. Dunstan JA, Mori TA, Barden A, Beilin LJ, Taylor AL, et al. (2003) Maternal fish oil supplementation in pregnancy reduces interleukin-13 levels in cord blood of infants at high risk of atopy. Clin Exp Allergy 33: 442-448.

23. Borres MP, Björkstén B (2004) Peripheral blood eosinophils and IL-4 in infancy in relation to the appearance of allergic disease during the first 6 years of life. Pediatr Allergy Immunol 15: 216-220.

24. van der Velden VH, Laan MP, Baert MR, de Waal Malefyt R, Neijens HJ, et al. (2001) Selective development of a strong Th2 cytokine profile in high-risk children who develop atopy: risk factors and regulatory role of IFN-gamma, IL-4 and IL-10. Clin Exp Allergy 31: 997-1006.

25. Croner S, Kjellman NI (1986) Predictors of atopic disease: cord blood IgE and month of birth. Allergy 41: 68-70.

26. Odelram H, Björkstén B, Leander E, Kjellman NI (1995) Predictors of atopy in newborn babies. Allergy 50: 585-592. 